\title{
Editorial
}

\section{International journal of disclosure and governance}

International Journal of Disclosure and Governance (2013) 10, 193-194. doi:10.1057/jdg.2013.27

It is with great pleasure that I write this Editorial for a selection of papers from the Centre for Corporate Governance Research (CCGR) 10th International Conference on Corporate Governance: 'Corporate Governance and Universal Acceptance: Taking Stock of Progress and Indicators of Future Trends' held at Birmingham Business School, University of Birmingham, United Kingdom on 25 June 2012.

The theme of the conference examined the extent to which there is universal acceptance of corporate governance and included papers which discussed developments in some of the key areas of corporate governance. The conference attracted widespread interest and conference delegates came from many countries across the globe, including India, the Netherlands, Canada, Portugal, Spain, United Arab Emirates, Hong Kong, Germany and Japan.

In this special issue there are five excellent papers: (i) 'Is Audit Failing the Global Capital Markets?' by Andrew D. Chambers; (ii) 'The Potential Implications of the Financial Reporting Expectations Gap for the Development of Corporate Governance' by Andrew Higson; (iii) 'The EU Law on Auditing and the Role of Auditors in the Global Financial Crisis of 2008' by Hatice Kubra Savas; (iv) 'The Personality of Company Directors and Behavioural Risks in Corporate Governance: Bridging the Unidentified Gap' by Ngozi Okoye; and (v) 'Collibration as an Alternative Regulatory Approach for Remuneration Governance: A Contextual Analysis of Australia' by Sangeeta Ray, Pradeep Ray, Zahid Riaz and James Kirkbride.
Andrew Chambers' article critically debates the various strands of research relating to the auditing profession and the challenges it faces in serving the public interest. He identifies various issues, which impact on the auditors' ability to act as an effective gatekeeper (for example, to warn about impending financial crisis). These issues include that auditing tends to be a boxticking exercise based on whether a company has followed the relevant accounting standards, even where this might lead to misleading results; the extent to which regulatory capture has been achieved by the profession; and conflicts of interest and their potential impact on independence. The article also highlights that internal auditors could develop to help give more board assurance.

Hatice Kubra Savas' article examines EU audit policy and the regulatory responses in relation to specific issues such as the appointment and remuneration of auditors; audit firm rotation; provision of non-audit services; the high concentration in the audit market (that is, a few firms - the Big4 - auditing the vast majority of large companies); and the expectations gap. The role of auditors in the financial crisis is also covered and there is insightful discussion of issues including the going concern judgement and the Big4 accountancy firms. The thorny problem of the auditor being both appointed and remunerated by the audit client highlights that auditors may tend to please their client in their interpretations of the company's accounts and financial situation; moreover, an expectations gap can be identified as the auditors will not be able to meet stakeholders' expectations as well. 
The expectations gap is also discussed in Andrew Higson's article, the focus of which is on the financial reporting expectations gap, which he writes comprises the audit expectations gap and the financial statements expectation gap, the latter being much less discussed in the literature. Given that financial statements have limitations, and without a real understanding of their scope, then the accountability of directors to shareholders and other stakeholders may be incomplete and problematic. This in turn may mean that there are issues relating to the effectiveness of corporate governance, for example, directors' accountability and also the fact that the directors' performance - and performance-related remuneration - is based on the company's financial statements.

James Kirkbride, Sangeeta Ray, Pradeep Ray and Zahid Riaz identify an alternative regulatory approach for remuneration, using collibration in the context of Australia. They define collibration, in this context, as a concept that explicitly addresses the governance interests of balancing market mechanisms with the need to recognise and protect private interests. A regulatory framework was developed in Australia, comprising a mix of state regulation and self-regulation, which was capable of accommodating conflicting interests, to help improve disclosure of directors/executives' remuneration. This was achieved through the alignment of state regulation, Corporate Law Economic Reform Program (CLERP 9), with selfregulation, Australian Securities Exchange (ASX) Corporate Governance Principles, by the Australian government.

The final paper in this special issue by Ngozi Okoye examines the interesting area of the personality aspect of behavioural risks. Inappropriate behaviour including a lack of personal ethics, a lack of regard for other people and a lack of moral responsibility has contributed to many corporate scandals and failures. This article points out that the corporate governance system is flawed if it does not include mechanisms for identifying the components of behavioural risk, and if there are not processes in place to manage the risks arising from these components. The personality of company directors is a significant behavioural risk contributor, which should be identified and managed, if it is not then this contributes to an ineffective corporate governance system.

Overall the five papers contribute to our understanding and provide useful insights of: auditors, one of the key gatekeepers, and the implications of lack of independence, conflicts of interest and other issues; the potential pitfalls of relying on financial statements without fully realising their limitations and the resulting lack of accountability of directors; the use of collibration to balance tensions between principals and agents; and the potential impact of directors' personalities in contributing to corporate failure.

Thank you to the authors for presenting their work at the 10th International Conference on Corporate Governance and for the 'final product' as we see published here. On a personal note, I retired from my role as Director of the CCGR when I left Birmingham Business School in the Autumn 2012. However, it has been a great pleasure to see this special issue come to fruition and to write the Editorial. I hope you enjoy this special issue.
Chris Mallin Special Edition Editor
Norwich Business School, University of East Anglia, Norwich, UK E-mail: C.Mallin@uea.ac.uk 